\title{
ANALISIS REGRESI DATA PANEL TERHADAP LIKUIDITAS SAHAM DI INDONESIA
}

\author{
Awidi Mulfita ${ }^{1)}$, Irdha Yusra ${ }^{2}$ \\ ${ }^{1,2)}$ Sekolah Tinggi Ilmu Ekonomi KBP \\ Email ${ }^{1)}$ : awidimft80@gmail.com \\ Email $^{2}$ : irdhayusra@akbpstie.ac.id
}

\begin{abstract}
In investing, investors don't assess the expected return, but also liquidity in shares. Because the aspect of liquidity is very important for investors to decide which stocks are attractive investments. This study aims to examine the effect of asset liquidity and financial leverage on stock liquidity. The population is all companies which are listed in Indonesia Stock Exchange in 2013-2017 periods. The sampling technique uses a purposive sampling method with predetermined criteria and obtained a sample of 58 companies with 290 observations. The data of the financial statement of the companies has been obtained from the official website of IDX. The analytical method used is regression analysis of panel data with the help of application E-Views 8. Panel data regression can be estimated using three models, namely Common Effect Model (CEM), Fixed Effect Model (FEM), and Random Effect Model (REM). From the results of the estimation model, it is found that REM is the best model in this study. Furthermore, the results of the study show that asset liquidity has a positive and not significant effect on stock liquidity, while financial leverage has a negative and significant effect on stock liquidity.
\end{abstract}

Keywords: Stock Liquidity, Liquidity of Assets, Financial Leverage

\begin{abstract}
ABSTRAK
Dalam berinvestasi, investor tidak hanya menilai dari return yang diharapkan, namun juga likuiditas pada saham. Karena aspek likuiditas sangat penting bagi investor untuk memutuskan mana saham yang menarik investasi. Penelitian ini bertujuan untuk menguji pengaruh likuiditas aset dan financial leverage terhadap likuiditas saham. Populasi dalam penelitian ini adalah perusahaan yang terdaftar di Bursa Efek Indonesia (BEI) periode 2013-2017. Teknik pengambilan sampel menggunakan metode purposive sampling dengan kriteria yang telah ditentukan dan diperoleh sampel sebanyak 58 perusahaan. Data laporan keuangan diperoleh dari website resmi BEI. Metode analisis yang dipakai adalah analisis regresi data panel dengan bantuan aplikasi E-Views 8. Regresi data panel dapat diestimasi menggunakan tiga model, yaitu Common Effect Model (CEM), Fixed Effect Model (FEM), dan Random Effect Model (REM). Untuk mendapatkan model terbaik digunakan uji lanjut, yaitu Uji Chow dan Uji Hausman. Dari hasil estimasi model diperoleh bahwa REM sebagai model terbaik dalam penelitian ini. Lebih lanjut, hasil penelitian menemukan bahwa likuiditas aset berpengaruh positif dan tidak signifikan terhadap likuiditas saham, sedangkan financial leverage berpengaruh negatif dan signifikan terhadap likuiditas saham.
\end{abstract}

Kata kunci: likuiditas saham, likuiditas aset, financial leverage

\section{PENDAHULUAN}


Pasar modal merupakan sebuah lembaga keuangan negara yang kegiatannya dalam perdagangan surat berharga. Untuk berinvestasi dalam pasar modal, investor harus mengetahui selain menerima keuntungan maka juga akan mengalami kerugian. Oleh karena itu, investor harus mengetahui informasi-informasi yang bisa dijadikan pedoman penting dalam menentukan pilihan dalam berinvestasi dengan berbagai alternatif yang tersedia. Salah satu hal yang akan dihadapi oleh investor dalam pasar modal yaitu tingkat keuntungan yang diharapkan, dimana return adalah hasil yang diperoleh dari investasi (Handayani, 2014).

Likuiditas saham menjadi salah satu faktor dalam berinvestasi yang perlu dipertimbangkan oleh investor. Dalam berinvestasi pada dasarnya sebagian investasi jangka panjang dengan orientasi pendapatan dividen, dan sebagian lainnya investasi jangka pendek pada capital gain. Likuiditas saham bagi investor jangka pendek sangat penting untuk melihat besar kecilnya keuntungan yang akan diperoleh. Karena kecepatan dan kemudahan transaksi pada suatu saham dapat dilihat dari tingkat likuiditas saham tanpa adanya penurunan harga (Sudana dan Intan, 2008).

Pada dasarnya, saham yang memiliki aktivitas transaksi yang tinggi bisa dikatakan sebagai saham yang likuid. Saham yang likuid ditentukan oleh banyaknya permintaan dan penawaran. Semakin besar volume permintaan dan penawaran aset sebuah saham, semakin likuid saham tersebut (Salim, 2010). Likuiditas saham juga merupakan salah satu karakteristik saham yang penting untuk dipertimbangkan oleh investor di Bursa Efek Indonesia (BEI). Saham yang semakin likuid akan lebih cepat dan mudah untuk diperjualbelikan. Investor yang melakukan investasi jangka pendek lebih baik memilih saham yang likuid dengan tujuan untuk mendapatkan capital gain, sehingga dapat digunakan untuk mengantisipasi pola pendapatan dan pembiayaan yang tidak teratur serta untuk memenuhi kebutuhan yang mendadak (Sudana dan Intan, 2008).

Pada penelitian ini, adapun yang mempengaruhi likuiditas saham seperti likuiditas aset yang sering disebut juga dengan likuiditas. Likuiditas adalah kewajiban yang harus dipenuhi dalam membiayai kewajiban jangka pendeknya. Perusahaan yang memiliki likuiditas yang tinggi tidak akan memanfaatkan pembiayaan dari utang, karena itu menunjukan bahwa perusahaan mempunyai dana internal yang besar (Fahmi, 2017). Likuiditas juga menunjukkan kemampuan suatu aktiva untuk dikonversikan menjadi kas. Ketika investor ingin menjual saham, maka investor lain siap untuk membeli dan jika investor ingin membeli saham, maka investor lainnya juga bersedia untuk menjual sahamnya. Transaksi yang dilakukan terhadap saham akan mendorong tingkat likuditas suatu saham. Semakin sering suatu saham ditransaksikan menunjukkan tingkat mobilitas yang tinggi dan semakin mudah saham tersebut (Wira, 2012).

Selain likuiditas aset, financial leverage juga dapat mempengaruhi likuiditas saham. Financial leverage adalah penggunaan sumber dana yang memiliki beban tetap yang nantinya dapat meningkatkan keuntungan bagi investor, keuntungan yang didapat lebih besar dari beban tetapnya. Dampak positif ataupun negatif dari peningkatan financial leverage terhadap pemegang saham tergantung pada kondisi perekonomian (Sudana dan Intan, 2008).

Rasio leverage merupakan seberapa besar perusahaan yang dibiayai dengan utang. Hal ini sangat diperhatikan oleh investor, terutama investor jangka panjang. Semakin besar utang semakin besar pula risiko bangkrutnya (Prihadi, 2008). 
Penggunaan hutang yang relatif tinggi akan menimbulkan biaya tetap (berupa biaya bunga) yang dapat meningkatkan risiko. Sehingga nantinya investor akan meminta tingkat keuntungan yang tinggi. Tingginya utang perusahaan berarti financial leverage pada perusahaan tersebut juga tinggi (Yusra, Hadya dan Fernandes, 2017).

Dampak likuiditas aset dan financial leverage terhadap likuiditas saham telah dilakukan kajian secara empiris oleh beberapa penelitian terdahulu. Penelitian Gopalan, Kadan dan Pevzner (2012) membuktikan adanya hubungan positif yang signifikan antara likuiditas aset dan likuiditas saham. Pada penelitian Norvaišien dan Stankevi (2014) pada perusahaan Estonia bahwa likuiditas aset berpengaruh positif terhadap likuiditas saham. Dan untuk financial leverage pada penelitian Norvaišien dan Stankevi (2014) pada perusahaan perusahaan Estonia berpengaruh negative dan signifikan terhadap likuiditas saham.

Pada penelitian ini yang menjadi kelebihan dari penelitian sebelumnya yaitu, dari segi metode (method) dengan menggunakan regresi data panel yang tidak dilakukan pada penelitian sebelumnya.

Faktor penting yang mempengaruhi likuiditas saham adalah likuiditas aset. Pada penelitian Gopalan, Kadan dan Pevzner (2012) membuktikan adanya hubungan positif yang signifikan antara likuiditas aset dan likuiditas saham. Choi dan Cook (2005) menemukan bahwa likuiditas saham dipengaruhi secara signifikan oleh rasio kewajiban jangka pendek terhadap aset, rasio kewajiban terhadap aset, rasio aset lancar terhadap jumlah aset, dan jumlah aset (Norvaišien dan Stankevi, 2014). Pada penelitian Norvaišien dan Stankevi (2014) pada perusahaan penelitian hubungan likuiditas saham Estonia dan mempengaruhi faktor-faktor tingkat perusahaan membuktikan bahwa saham perusahaan dengan likuiditas aset yang lebih tinggi, dan menghasilkan laba juga lebih likuid. Adapun hipotesis yang dirumuskan pada pengamatan ini yaitu :

\section{H1 : Likuiditas Aset berpengaruh positif dan signifikan terhadap Likuiditas Saham}

Selain itu, financial leverage juga berpengaruh terhadap likuiditas saham. Pada umumnya perusahaan yang lebih banyak menggunakan modal sendiri daripada modal asing cenderung mendapatkan keuntungan. Ketika dana yang dibutuhkan kurang mencukupi maka perusahaan akan menggunakan modal asing, dan yang tanggungan terhadap keseluruhan risiko perusahaan serta jaminan bagi para kreditur adalah modal sendiri. Dengan demikian, perusahaan perlu adanya kebijakan dalam menentukan penggunaan modal mana yang lebih baik dalam memenuhi kegiatan operasionalnya (Fahmi, 2017).

Dalam penelitian Norvaišien dan Stankevi (2014) yang berjudul "Impact of companies internal factors on stock liquidity in Baltic Markets", penelitian hubungan likuiditas saham Lithuania dan mempengaruhi faktor-faktor tingkat perusahaan membuktikan korelasi yang signifikan antara penyebaran harga bid/ask dan leverage keuangan, antara penyebaran harga bid/ask dan laba atas aset dan antara penyebaran harga bid/ask spread dan ukuran perusahaan. Hubungan antara penyebaran harga bid/ask dan leverage keuangan bersifat langsung, yaitu rasio hutang terhadap ekuitas yang lebih tinggi mempengaruhi meningkatnya penyebaran harga bid/ask. Ini menunjukkan bahwa leverage keuangan yang lebih tinggi dari 
perusahaan Lituania mengarah ke likuiditas saham yang lebih rendah. Adapun hipotesis yang dirumuskan pada pengamatan ini yaitu :

\section{$\mathrm{H}_{2}$ : Financial Leverage berpengaruh negatif dan signifikan terhadap Likuiditas Saham}

\section{METODE PENELITIAN}

\section{Data dan Sampel}

Penelitian ini dilakukan pada perusahaan yang terdaftar di Bursa Efek Indonesia. Alasan pemilihan obyek ini adalah dalam pemilihan sampel tidak terdapat kendala kekurangan data, dan titik informasi yang pasti mengenai industri yang telah go publik.

Dalam penelitian ini, Annual Report dan Summary digunakan sebagai sumber data utama. Jenis data yang didapatkan dari Annual Report dan Summary berupa data kuantitatif. Data kuantitatif yang digunakan seperti laporan laba rugi, laporan ekuitas, laporan neraca. Teknik pengumpulan data yang digunakan dalah dokumentasi.

Populasi pada pengamatan ini yaitu Perusahaan yang terdaftar pada Bursa Efek Indonesia di akhir periode observasi, yaitu 2017 sebanyak 539 Perusahaan. Metode pemilahan sampel pada pengamatan ini dilakukan dengan metode purposive sampling yaitu metode penarikan sampel dengan penilaian yang berdasarkan pada kriteria sesuai dengan objek maupun subjek yang untuk diamati. Kriteria untuk pengambilan sampel pada pengamatan ini yaitu :

1. Perusahaan terdaftar di BEI akhir periode observasi, yaitu Tahun 2017.

2. Perusahaan terdaftar di BEI berturut-turut selama periode observasi (20132017).

3. Perusahaan terdaftar di BEI yang menerbitkan laporan keuangan selama periode observasi (2013-2017).

4. Perusahaan yang menyediakan data keuangan sesuai variable yang diuji yaitu likuiditas saham, likuiditas aset, dan financial leverage.

Berdasarkan kriteria-kriteria tersebut, maka diperoleh sampel pada Tabel berikut:

\section{Tabel 1}

Tabulasi Pengambilan Sampel Menggunakan Purposive Sampling

\begin{tabular}{clc}
\hline No & \multicolumn{1}{c}{ Kiteria } & Jumlah \\
\hline 1 & $\begin{array}{l}\text { Perusahaan terdaftar di BEI akhir periode observasi, yaitu } \\
\text { Tahun 2017. }\end{array}$ & 539 \\
2 & $\begin{array}{l}\text { Perusahaan tidak terdaftar di BEI berturut-turut selama } \\
\text { periode observasi (2013-2017). }\end{array}$ & $(142)$ \\
3 & $\begin{array}{l}\text { Perusahaan terdaftar di BEI yang tidak menerbitkan laporan } \\
\text { keuangan selama periode observasi (2013-2017). }\end{array}$ & (84) \\
4 & $\begin{array}{l}\text { Perusahaan yang tidak menyediakan data keuangan sesuai } \\
\text { variable yang diuji yaitu likuiditas saham, likuiditas aset, dan } \\
\text { financial leverage. }\end{array}$ & \multicolumn{1}{c}{ Jumlah Sampel Akhir } \\
\hline
\end{tabular}




\begin{tabular}{ccc}
\hline No & Kiteria & Jumlah \\
\hline & Jumlah Observasi & 290 \\
\hline
\end{tabular}

sumber : Diolah Peneliti, 2018

\section{Definisi Operasional Variabel}

Dalam penelitian ini terdiri dari dua macam variabel yaitu variabel independent dan dependent. Variabel independent yaitu Likuiditas Aset $\left(\mathrm{X}_{1}\right)$, dan Financial Leverage $\left(\mathrm{X}_{2}\right)$. Variabel dependent yaitu Likuiditas Saham (Y). Selanjutnya dapat diuraikan definisi operasionalnya dari pengamatan ini sebagai berikut:

Tabel 2

Definisi Operasional Variabel

\begin{tabular}{|c|c|c|c|c|}
\hline No & Variabel & Definisi & Pengukuran & Sumber \\
\hline 1 & $\begin{array}{l}\text { Likuiditas } \\
\text { Saham } \\
\text { (Y) }\end{array}$ & $\begin{array}{l}\text { Bid-ask spread } \\
\text { merupakan } \\
\text { perbandingan antara } \\
\text { selisih High (harga } \\
\text { tinggi saham) dan } \\
\text { Low (harga rendah } \\
\text { saham) dibagi dengan } \\
\text { High (harga tinggi } \\
\text { saham). }\end{array}$ & $\begin{array}{l}\text { Bid-ask Spread }= \\
\frac{\text { High-Low }}{\text { High }} \times 100\end{array}$ & $\begin{array}{l}\text { Norvaiši } \\
\text { en dan } \\
\text { Stankevi } \\
, 2014\end{array}$ \\
\hline \multirow[t]{2}{*}{2} & \multirow[t]{2}{*}{$\begin{array}{l}\text { Likuiditas } \\
\text { Aset } \\
\left(\mathrm{X}_{1}\right)\end{array}$} & $\begin{array}{l}\text { Current Ratio } \\
\text { merupakan rasio yang } \\
\text { membandingkan } \\
\text { amtara current assets } \\
\text { dibagi dengan current } \\
\text { liabilities. }\end{array}$ & $\begin{array}{l}\text { Current Ratio= } \\
\frac{\text { Current Assets }}{\text { Current Liabilities }} \times 100 \%\end{array}$ & \multirow[t]{2}{*}{$\begin{array}{l}\text { Fahmi, } \\
2016\end{array}$} \\
\hline & & $\begin{array}{l}\text { Quick Ratio } \\
\text { merupakan rasio yang } \\
\text { membandingkan } \\
\text { antara current assets } \\
\text { (CA) dikurangi } \\
\text { inventories dibagi } \\
\text { dengan } \text { current } \\
\text { liabilities. }\end{array}$ & $\begin{array}{l}\text { Quick Ratio }= \\
\frac{\text { CA-Inventories }}{\text { Current Liabilities }} \times 100 \%\end{array}$ & \\
\hline 3 & $\begin{array}{l}\text { Financial } \\
\text { Leverage } \\
\quad\left(X_{2}\right)\end{array}$ & $\begin{array}{l}\text { Debt to Equity Ratio } \\
\text { merupakan rasio yang } \\
\text { membandingkan } \\
\text { antara total debt } \\
\text { dibagi dengan total } \\
\text { equity. }\end{array}$ & $D E R=\frac{\text { Total Debt }}{\text { Total Equity }}$ & $\begin{array}{l}\text { Fahmi, } \\
2016\end{array}$ \\
\hline
\end{tabular}

\section{Teknik Analisis Data}

Dalam penelitian ini dilakukan pengujian hipotesis yang bertujuan menguji pengaruh likuiditas aset dan financial leverage terhadap likuiditas saham. Data yang digunakan pada penelitian ini yaitu data panel, yang merupakan gabungan 
antara data time series dan cross section. Data sampel sebanyak 58 perusahaan diambil dari data unit cross section dan data time series periode 2013-2017.

Analisis statistik deskriptif merupakan metode analisis yang digunakan dalam penelitian ini dan menggunakan Program Eviews (Winarno, 2015) untuk analisis regresi data panel. Persamaan regresi data panel yang digunakan dalam penelitian ini adalah:

$$
\mathbf{L S}_{\mathrm{it}}=\alpha+\boldsymbol{\beta}_{1} \mathbf{L} \mathbf{A}_{\mathrm{it}}+\boldsymbol{\beta}_{2} \mathbf{F} \mathbf{L}_{\mathrm{it}}+\mathbf{e}
$$

Dimana LSit merupakan Likuiditas Saham Perusahaan pada waktu t, $\alpha$ merupakan konstanta (intercept), $\beta 1, \beta 2$ merupakan Koefisien Regresi, LAit merupakan Likuiditas Aset (proksi Quick Ratio) Perusahaan pada waktu t, FLit merupakan Financial Leverage Perusahaan pada waktu t dan e merupakan Standar error.

Pendekatan yang dilakukan dalam analisis regresi data panel yaitu common effect model (CEM), Fixed effect Model (FEM), random effect model ( REM) (Wulandari, 2017). Ada dua tahapan yang dilakukan untuk menentukan model yang terbaik digunakan antara model tersebut yaitu: Chow Test, untuk menentukan model mana yang terbaik antara common effect model (CEM) dengan Fixed effect Model (FEM). Hausman Test, dilakukan untuk menentukan model mana yang terbaik digunakan antara Fixed effect Model (FEM) dengan random effect model ( REM). Model regresi yang baik harus menghasilkan estimasi linear tidak bias (Best Linear Unbiased Estimator) (Hadya, Begawati, dan Yusra, 2017).

\section{HASIL DAN PEMBAHASAN Uji Statistik Deskriptif Variabel}

Tabel 3

Hasil Uji Statistik Deskriptif

\begin{tabular}{ccccc}
\hline Variabel & Minimum & Maksimum & Mean & $\begin{array}{c}\text { Standar } \\
\text { Deviasi }\end{array}$ \\
\hline $\begin{array}{c}\text { Likuiditas Saham } \\
\text { (LS) }\end{array}$ & 11.29000 & 98.29000 & 46.95183 & 18.05497 \\
$\begin{array}{c}\text { Likuiditas Aset } \\
\text { (LA) }\end{array}$ & 13.27000 & 218.9300 & 90.41176 & 47.64658 \\
$\begin{array}{c}\text { Financial } \\
\text { Leverage (FL) }\end{array}$ & 0.240000 & 18.07000 & 1.572241 & 1.510442 \\
\hline Sumber : data diolah, Eview & & \multicolumn{3}{c}{$s 8$}
\end{tabular}

Pada tabel 3 menunjukkan angka-angka deskriptif dari masing-masing variabel dengan jumlah observasi sebanyak 290 (dua ratus sembilan puluh). Penjelasan dari analisis deskriptif adalah sebagai berikut :

Likuiditas saham merupakan variabel terikat dengan menggunakan bid-ask spread sebagai alat ukur. Nilai minimum sebesar $11.29 \%$ berarti bahwa perusahaan masih lambat atau mengalami kendala dalam memperjualbelikan saham untuk dikonversikan menjadi kas. Adapun perusahaan yang memiliki nilai minimum yaitu pada PT First Media Tbk tahun 2013. Nilai maksimum sebesar 98.29\% berarti bahwa perusahaan dapat memperjualbelikan saham secara cepat dan mudah sehingga bisa dikonversikan menjadi kas. Perusahaan yang memiliki nilai maximum adalah PT Pelat Timah Nusantara Tbk pada tahun 2016.Nilai rata-rata 
(mean) sebesar 46.95 berarti bahwa selisih antara nilai high dengan low lebih besar dari pada nilai high. Nilai standar deviasi sebesar 18.05 yang menunjukkan penyebaran data yang lebih kecil karena nilainya lebih rendah dari nilai rata-rata (mean).

Quick ratio merupakan indikator dari likuiditas aset. Nilai minimum quick ratio sebesar $13.27 \%$, menunjukkan kemampuan perusahaan untuk membayar kewajiban jangka pendek dengan menggunakan aset lancar dikurangi dengan inventories (persediaan). Adapun perusahaan yang memiliki nilai minimum adalah PT MNC Sky Vision Tbk tahun 2015. Nilai maximum quick ratio sebesar $218.93 \%$ menunjukan kemampuan perusahaan untuk membayar kewajiban jangka pendek dengan menggunakan aset lancar dikurangi dengan inventories (persediaan). Perusahaan yang memperoleh nilai maximum adalah PT Aneka Tambang (Persero) Tbk tahun 2015. Nilai rata-rata (mean) quick ratio sebesar 90.41 menunjukkan kemampuan perusahaan untuk membayar kewajiban jangka pendek dengan menggunakan aset lancar dikurangi dengan inventories lebih besar dibandingkan dengan utang lancar. Standar deviasi quick ratio sebesar 47.64 yang menunjukkan penyebaran data yang lebih kecil karena nilainya lebih rendah dari nilai rata-rata (mean).

Indikator DER (Debt to Equity Ratio) digunakan sebagai alat ukur pada variabel independen financial leverage. Nilai minimum DER (Debt to Equity Ratio) sebesar 0.24 berarti perusahaan lebih sedikit memanfaatkan utang dibandingkan dengan ekuitas yang dimiliki oleh perusahaan. Adapun perusahaan yang memiliki nilai minimum diperoleh oleh PT Hotel Mandarine Regency Tbk pada tahun 2015. Nilai maximum DER (Debt to Equity Ratio) sebesar 18.07 yang berarti bahwa perusahaan lebih banyak memanfaatkan hutang dibandingkan dengan ekuitas yang dimiliki oleh perusahaan yang diperoleh PT Wahana Pronatural Tbk tahun 2016. Nilai rata-rata (mean) sebesar 1.57 artinya diatas 1 menunjukkan bahwa total hutang lebih besar dari pada ekuitas. Sedangkan standar deviasi dari DER (Debt to Equity Ratio) sebesar 1.51 yang menunjukkan penyebaran data lebih kecil karena nilainya lebih rendah dari nilai rata-rata (mean).

\section{Pemilihan Regresi Data Panel}

Dalam data panel untuk pemilihan model yang terbaik dilakukan tahap analisis dengan cara melakukan estimasi model Common Effect (CEM), Fixed Effect (FEM), dan Random Effect (REM). Persamaan regresi likuiditas aset dengan menggunakan proksi quick ratio adalah sebagai berikut:

$$
\operatorname{LogLS}_{i t}=\alpha+\beta 1 \operatorname{LogLA} A_{i t}+\beta 2 \operatorname{LogFL} L_{i t}+e_{i t}
$$

Persamaan ini menggunakan transformasi logaritma dalam menentukan model yang terbaik. Hasil statistik yang diperoleh dalam pengestimasian model CEM, FEM, dan REM adalah sebagai berikut:

\section{Tabel 4}

Tabel Estimasi CEM, FEM, dan REM

\begin{tabular}{ccccccc}
\hline \multirow{2}{*}{ Variabel } & \multicolumn{2}{c}{ Common Effect } & \multicolumn{2}{c}{ Fixed Effect } & \multicolumn{2}{c}{ Random Effect } \\
\cline { 2 - 7 } & t-statistik & prob & t-statistik & prob & t-statistik & prob \\
\hline LA & 0.7749 & 0.4390 & 0.0925 & 0.9264 & 0.6473 & 0.5179
\end{tabular}


\begin{tabular}{lllllll} 
FL & -0.9633 & 0.3362 & -2.2142 & 0.0278 & -1.1157 & 0.2655 \\
\hline
\end{tabular}

Sumber : data diolah, Eviews 8

Tabel 4 menunjukkan hasil estimasi menjelaskan bahwa masing-masing model memiliki nilai signifikansi yang berbeda-beda. Untuk menemukan model mana yang terbaik maka dilakukan analisis lebih lanjut dengan menggunakan Chow Test dan Hausman Test.

Sebelum pengujian lanjutan di estimasi, maka dilakukan uji normalitas terlebih dahulu. Asumsi normalitas hanya terpenuhi pada Fixed Effect Model (FEM). Adapun hasil pengujian sebagai berikut :

Tabel 7

Hasil Uji Normalitas

\begin{tabular}{cc}
\hline Jarque-Bera & Probability \\
\hline 3.259478 & 0.195981 \\
\hline
\end{tabular}

\section{Sumber :data diolah, Eviews 8}

Berdasarkan tabel 11 diatas, hasil estimasi likuiditas aset dengan menggunakan quick ratio indikator terhadap likuiditas saham didapatkan. Nilai probability lebih besar dari alpha $(0.195981>0.05)$ maka dapat dikatakan bahwa residual dalam model penelitian ini telah terdistribusi normal.

Hasil Chow Test dapat dilihat pada tabel berikut ini:

Tabel 5

Chow Test

\begin{tabular}{lrrr}
\hline Effects Test & Statistic & d.f. & Prob. \\
\hline \hline Cross-section F & 1.468423 & $(57,230)$ & 0.0260 \\
Cross-section Chi-square & 90.003849 & 57 & 0.0035 \\
\hline Sumber : data diolah, Eviews 8 & & &
\end{tabular}

Uji chow bertujuan untuk menentukan model yang lebih baik digunakan antara model Common Effect dan Fixed Effect. Pada tabel di atas diperoleh nilai prob pada Cross-section Chi-square lebih kecil dari alpha $(\alpha)(0.0000<0.05)$, maka H0 ditolak. Artinya model Fixed Effect lebih baik digunakan dari model Common Effect.

\section{Analisis Regresi Data Panel}

Dalam penelitian ini teknik analisis data digunakan untuk mengolah, membahas sampel yang sudah diperoleh dan untuk menilai hipotesis yang diduga. Hasil pengujian penelitian dengan likuiditas menggunakan indikator quick ratio dapat dilihat pada tabel berikut:

\section{Tabel 8}


Tabel Hasil Estimasi Regresi Data Panel

\begin{tabular}{ccccc}
\hline Variable & Coefficient & Std. Error & t-Statistic & Prob. \\
\hline C & 3.770024 & 0.410003 & 9.195125 & 0.0000 \\
LA & 0.008605 & 0.093023 & 0.092509 & 0.9264 \\
FL & -0.194553 & 0.087863 & -2.214276 & 0.0278 \\
\hline
\end{tabular}

Sumber: data diolah, Eviews 8

Persamaan Regresi Data Panel Fixed Effect Model adalah sebagai berikut:

$$
\mathrm{LS}_{\mathrm{it}}=3.7700+0.0086 \text { LAit }-0.1945 \text { FLit }
$$

Angka pada persamaan regresi data panel didapatkan dari nilai coefficient variabel. Nilai konstanta sebesar 3.7700 ini menjelaskan jika diasumsikan nilai variabel independen bernilai 0 (tidak ada), maka nilai likuiditas saham bernilai tetap sebesar 3.7700. Koefisien likuiditas aset (quick ratio) sebesar 0.0086 artinya setiap peningkatan variabel likuiditas aset sebanyak 1 satuan berarti akan meningkatkan variabel likuiditas saham sebesar 3.7700 serta beranggapan variabel lain dalam bentuk konstan. Koefisien financial leverage sebesar -0.1945 artinya setiap peningkatan variabel likuiditas sebanyak 1 satuan berarti akan menurunkan variabel likuiditas saham sebanyak -0.1945 serta beranggapan variabel lain dalam bentuk konstan.

\section{Hasil Pengujian Hipotesis}

Pengujian hipotesis pertama yang terlihat pada Tabel 8 menunjukkan hasil yang bertolak belakang dengan hipotesis yang dibangun. Pengujian menunjukkan nilai t-hitung lebih kecil dari t-tabel $(0.0925<1.9682)$ atau probability lebih besar dari alpha (0.9264>0.05), maka hipotesis pertama $\left(\mathrm{H}_{1}\right)$ dalam penelitian ditolak. Artinya likuiditas aset tidak berpengaruh terhadap likuiditas saham. Untuk variabel financial leverage secara absolut menunjukkan nilai t-hitung lebih besar dari t-tabel $(2.2142<1.9682)$ atau probability lebih kecil dari alpha $(0.0278<0.05)$, maka hipotesis kedua $\left(\mathrm{H}_{2}\right)$ diterima. Dengan demikian dapat disimpulkan bahwa financial leverage berpengaruh negatif dan signifikan terhadap likuiditas saham.

\section{PEMBAHASAN}

\section{Pengaruh Likuiditas Aset terhadap Likuiditas Saham}

Berdasarkan hipotesis pertama $\left(\mathrm{H}_{1}\right)$ yang dikemukakan dalam penelitian ini yaitu, bahwa diduga likuiditas aset berpengaruh positif dan signifikan terhadap likuiditas saham. Sedangkan berdasarkan hasil uji nilai t hitung untuk variabel likuiditas aset membuktikan bahwa $\mathrm{H}_{1}$ ditolak. Artinya tidak ada pengaruh yang signifikan antara likuiditas aset terhadap likuiditas saham.

Hal ini dikarenakan bahwa naik turunnya tingkat likuiditas saham, tidak dipengaruhi oleh likuiditas aset. Dalam arti kata, likuiditas aset tidak berkontribusi terhadap likuiditas saham. Secara operasional, likuiditas saham tidak ditentukan oleh current asset, current liabilities, dan inventories yang terdapat dalam likuiditas aset. Sedangkan likuiditas aset tidak ditentukan oleh harga jual dan harga beli saham.

Selain itu, hal ini bisa disebabkan oleh banyaknya data yang tereliminasi pada waktu penyeleksian data yang telah dilakukan karena banyaknya data yang outliers. 
Banyaknya data outliers (ekstrim) dikarenakan perusahaan yang dijadikan sampel berasal dari sektor yang berbeda.

\section{Pengaruh Financial Leverage terhadap Likuiditas Saham}

Berdasarkan hipotesis kedua $\left(\mathrm{H}_{2}\right)$ yang dikemukakan dalam penelitian ini yaitu diduga bahwa Financial Leverage berpengaruh negatif dan signifikan terhadap Likuiditas Saham. Dari hasil uji nilai t-hitung untuk variabel Financial Leverage membuktikan bahwa $\mathrm{H}_{2}$ diterima. Artinya ada pengaruh yang signifikan antara Financial Leverage terhadap Likuiditas Saham.

Perusahaan yang lebih banyak menggunakan modal sendiri daripada modal asing cenderung mendapatkan keuntungan. Ketika dana yang dibutuhkan kurang mencukupi maka perusahaan akan menggunakan modal asing, dan yang tanggungan terhadap keseluruhan risiko perusahaan serta jaminan bagi para kreditur adalah modal sendiri. Dengan demikian, perusahaan perlu adanya kebijakan dalam menentukan penggunaan modal mana yang lebih baik dalam memenuhi kegiatan operasionalnya (Fahmi, 2017). Maka, dari hasil penelitian ini dapat disimpulkan bahwa semakin kecil suatu hutang perusahaan, berarti perusahaan memiliki dana internal yang mampu memenuhi kegiatan operasionalnya. Sehingga jika tingkat likuiditas saham tetap optimal tanpa harus meminjam dana eksternal dalam memenuhi kewajiban jangka pendeknya.

Selain itu, hasil penelitian ini sesuai dengan penelitian sebelumnya yang dilakukan oleh Norvaišien dan Stankevi (2014) tentang dampak faktor internal perusahaan pada likuiditas saham di pasar Baltik. Pada penelitian tersebut membuktikan bahwa financial leverage pada perusahaan Estonia berpengaruh negatif dan signifikan terhadap likuiditas saham.

\section{SIMPULAN}

Hasil dari penelitian pengaruh Likuiditas Aset (LA) dan Financial Leverage $(F L)$ terhadap Likuiditas Saham (LS) dapat disimpulkan bahwa yang pertama, Likuiditas Aset (LA) berpengaruh positif dan tidak signifikan terhadap likuiditas saham pada perusahaan yang terdaftar di Bursa Efek Indonesia periode 2013-2017. Artinya, likuiditas aset tidak berkontribusi terhadap likuiditas saham. Kedua, Financial Leverage $(F L)$ berpengaruh negatif dan signifikan terhadap likuiditas saham pada perusahaan yang terdaftar di Bursa Efek Indonesia periode 2013-2017. Artinya, perusahaan memiliki dana internal yang mampu memenuhi kegiatan operasionalnya. Sehingga tingkat likuiditas saham tetap optimal tanpa harus meminjam dana eksternal dalam memenuhi kewajiban jangka pendeknya.

\section{UCAPAN TERIMA KASIH}

Peneliti mengucapkan terima kasih kepada pihak-pihak yang telah memberikan dukungan dan dorongan dalam melakukan penelitian ini. Penghargaan dan ucapan terima kasih kepada Bursa Efek Indonesia yang telah menyediakan akses ke dalam laporan keuangan tahunan (annual report) perusahaan yang terdaftar di BEI. Sehingga memudahkan peneliti untuk mengumpulkan data sesuai dengan data yang peneliti butuhkan. Penghargaan dan terima kasih juga penulis ucapkan kepada Ketua Sekolah Tinggi Ilmu Ekonomi "Keuangan Perbankan dan Pembangunan", 
terutama Program Studi Manajemen yang telah memberikan motivasi dan dukungan kepada penulis untuk melakukan penelitian dan penulisan jurnal ini.

\section{DAFTAR PUSTAKA}

Fahmi, I. (2016). Pengantar Manajemen Keuangan. (M. B. . Muslim A. Djalil, S.E., Ak., Ed.). Bandung: ALFABETA, CV.

Fahmi, L. Z. (2017). Pengaruh Struktur Aktiva, Ukuran Perusahaan, dan Likuiditas terhadap Struktur Modal. Jurnal Ilmu Dan Riset Akuntansi, 6(2), 1-19.

Gopalan, R., Kadan, O., \& Pevzner, M. (2012). Asset Liquidity and Stock Liquidity. Journal of Financial and Quantitative Analysis, 47(2), 333-364. https://doi.org/10.1017/S0022109012000130

Hadya, R., Begawati, N., \& Yusra, I. (2017). Analisis Efektivitas Pengendalian Biaya, Perputaran Modal Kerja, Dan Rentabilitas Ekonomi Menggunakan Regresi Data Panel. Jurnal Pundi, 1(3), 153-166.

Handayani, D. W. (2014). Pengaruh Financial Leverage, Likuiditas , Pertumbuhan Asset, dan Ukuran Perusahaan terhadap Beta Saham Pada Perusahaan Manufaktur Yang Terdaftar di Bursa Efek Indonesia, 1(2), 169-182.

Norvaišien, R., \& Stankevi, J. (2014). Impact of companies' internal factors on stock liquidity in Baltic markets. Procedia - Social and Behavioral Sciences, 156, 543-547. https://doi.org/10.1016/j.sbspro.2014.11.237

Prihadi, T. (2008). 7 Analisis Rasio Keuangan (1st ed.). Jakarta: PPM.

Salim, J. (2010). Cara Gampang Bermain Saham. Jakarta: Visimedia.

Sudana, I. M., \& Intan, N. (2008). Leverage Keuangan dan Likuiditas Saham Perusahaan Manufaktur yang Terdaftar di Bursa Efek Jakarta. Manajemen Teori Dan Terapan, 1(3), 127-143.

Winarno, wing wahyu. (2015). Analisis Ekonometrika dan Statistika dengan Eviews (4th ed.). Yogyakarta: Upp Stim Ykpn.

Wira, V. (2012). Pengaruh Kinerja Perusahaan terhadap Likuiditas Saham Menggunakan Trading Turnover. Manajemen Dan Kewirausahaan, 3(2), 97120.

Wulandari, N. (2017). Analisis Faktor-Faktor yang Mempengaruhi Inflasi pada Kota Metropolitan di Indonesia dengan Menggunakan Analisis Data Panel. Sains Matematika Dan Statistika, 3(2), 34-42.

Yusra, I., Hadya, R., \& Fernandes, J. (2017). Likuiditas, Financial Leverage, dan Prediktabilitas Beta: Pendekatan Fowler And Rorke Sebagai Metode Koreksi Beta. Jurnal Benefita, 2(1), 81-91. 